\title{
Effects of Schizochytrium microalgae and sunflower oil as sources of unsaturated fatty acids for the sustainable mitigation of ruminal biogases methane and carbon dioxide
}

\author{
M.M.Y. Elghandour ${ }^{\text {a }}$, L.H. Vallejo ${ }^{\text {a }}$, A.Z.M. Salem ${ }^{\text {a, }}{ }^{*}$, M.Z.M. Salem ${ }^{\text {b }}$, L.M. Camacho ${ }^{\text {, }}$, \\ G. Buendía R ${ }^{\mathrm{d}}$, N.E. Odongo ${ }^{\mathrm{e}}$ \\ a Facultad de Medicina Veterinaria y Zootecnia, Universidad Autónoma del Estado de México, Estado de México, Mexico \\ ${ }^{\mathrm{b}}$ Forestry and Wood Technology Department, Faculty of Agriculture (EL-Shatby), Alexandria University, Alexandria, Egypt \\ ${ }^{c}$ Unidad Académica de Medicina Veterinaria y Zootecnia, Universidad Autónoma de Guerrero, Cd. Altamirano, Guerrero, Mexico \\ ${ }^{d}$ Centro Nacional de Investigación Disciplinaria en Fisiología y Mejoramiento Animal, INIFAP, Ajuchitlán, Querétaro, 76280, Mexico \\ e Department of Animal Sciences, School of Agriculture, Pwani University, P. O. Box, 195-80108, Kilifi, Kenya
}

\section{A R T I C L E I N F O}

\section{Article history:}

Received 6 February 2017

Received in revised form

19 July 2017

Accepted 4 September 2017

Available online 6 September 2017

\section{Keywords:}

Biogases

In vitro fermentation

Microalgae

Sunflower oil

\begin{abstract}
A B S T R A C T
Mitigation of methane $\left(\mathrm{CH}_{4}\right)$ and carbon dioxide $\left(\mathrm{CO}_{2}\right)$ emissions as well as ruminal fermentation parameters of a total mixed ration in the presence of Schizochytrium microalgae (SA) and sunflower oil (SO) or their mixture (SASO) as unsaturated fatty acid sources was investigated. Rumen liquor from two rumen cannulated Holstein steers and two rumen cannulated Creole goats was used as inoculum. Interactions between inoculum source $\times$ additive type, and inoculum source $\times$ additive type $\times$ dose were observed for gas, $\mathrm{CH}_{4}$ and $\mathrm{CO}_{2}$ production and fermentation parameters. Additives affected the fermentation parameters in a dose-dependent manner. With goats' inoculum, the inclusion of SO (1, 2, 4, $5 \%)$, SA $(2,3,5 \%)$ and SASO (1,3\%) increased gas production (GP) and decreased the rate of GP, while with the steer inoculum, SO at 1 and 4\% increased GP and the rate of GP. All levels of SA and SASO decreased the asymptotic GP and increased the rate of GP. The goat inoculum decreased $\mathrm{CH}_{4}$ at different doses of SO, SA and SASO whereas the steer inoculum decreased $\mathrm{CH}_{4}$ production. At all doses, additives decreased fermentation $\mathrm{pH}$, protozoal counts, and increased ammonia-N, DM degradability and total bacterial counts. Sunflower oil (i.e., SO) at $1-3 \%$, SA at $1-2 \%$, and SASO at $1-2 \%$ were the most efficacious in the nutrition of goats, compared with SO at 1 to 2 in steers. The results suggest that Schizochytrium microalgae and sunflower oil could be a valuable means of sustainably mitigating $\mathrm{CH}_{4}$ and $\mathrm{CO}_{2}$ emissions for improved environmental conditions.
\end{abstract}

(c) 2017 Elsevier Ltd. All rights reserved.

\section{Introduction}

Biogases produced during ruminant production needs to be reduced. The Food and Agriculture Organization (FAO) estimated $\mathrm{CH}_{4}$ production from livestock to contribute about $18 \%$ of all greenhouse gas emissions, while carbon dioxide $(\mathrm{CO} 2)$ accounted for about $9 \%$ of the emission (FAO, 2006). Besides, these gases including $\mathrm{CH}_{4}, \mathrm{CO}_{2}$, and $\mathrm{H}_{2}$ are produced during ruminal fermentation and cause losses amounting to $2-12 \%$ of dietary energy in ruminants (Johnson and Johnson, 1995). Furthermore, these emissions have been implicated in causing climate change. Yeast,

\footnotetext{
* Corresponding author.

E-mail address: asalem70@yahoo.com (A.Z.M. Salem).
}

organic acids salt, exogenous enzymes, and essential oils have been used as new strategies to mitigate the production of ruminal methane from ruminants (Elghandour et al., 2016, 2017; Hernandez et al., 2017).

The biogases production from ruminants could be reduced with inclusion of lipids in ruminant diets (Hook et al., 2010), which has been attributed to a reduction of ruminal protozoal concentrations in the rumen (Abubakr et al., 2013). Dietary lipids rich in docosahexaenoic acid (DHA) have been reported to enhance the nutritive value of the product of ruminant production (e.g., milk and meat), and improve animal performance (Kholif et al., 2016).

Vegetable oils and microalgae are rich sources of unsaturated fatty acids (UFA) including DHA and conjugated linoleic acid (CLA, Kelly et al., 2003). Addition of vegetable oils to the lactating animal 
rations has been used as a strategy to alter the proportion of saturated (SFA) and UFA in animal products through the extensive ruminal biohydrogenation (Kholif et al., 2016). Linoleic acid is the main compound in sunflower oil (i.e., SO), which may increase CLA in the animal product (Morsy et al., 2015). Furthermore, feeding vegetable oils to lactating goats modified the FA profile without any negative effects on ruminal fermentation or nutrients digestibility (Morsy et al., 2015; Kholif et al., 2016).

Microalgae (Schizochytrium spp.), is a microalgae rich in dietary FA and protein content making it a potential feed supplement to improve feed utilization and animal performance (Burnett et al., 2017). Schizochytrium microalgae is a rich source of long-chain PUFA including DHA and eicosapentaenoic acid (EPA), therefore, it can be used to inhibit the in vitro biohydrogenation of FA, resulting in reduction in SFA amount of SFA and an increase in UFA (Boeckaert et al., 2007). Schizochytrium microalgae have also been shown to increase the concentration of DHA in the milk of dairy animals (Moate et al., 2013).

Improving feed utilization and animal performance is the main goal for nutritionists; however, social and environmental obligations to reduce biogases emission are crucial for the sustainable intensification of livestock production. The present experiment aimed to study the effect of including SO and/or SA as UFA sources on in vitro ruminal fermentation for the sustainable mitigation of $\mathrm{CH}_{4}$ and $\mathrm{CO}_{2}$ emissions using rumen inoculums from steers and goats fed the same diet. The hypothesis was that differences among ruminant species and different sources of dietary fats would alter ruminal microflora resulting in improved dietary nutritive value and reduced biogases production.

\section{Materials and methods}

\subsection{Preparation of total mixed ration and treatments}

The composition of total mixed ration prepared as a substrate is shown in Table 1 . The total mixed ration without additive was considered as the control treatment. Schizochytrium microalgae (Xuhuang Bio-Tech Co., Ltd., Shaanxi, China) and SO from a local supplier, were individually or their mixture at 1:1 DM basis (SASO) added to the total mixed ration at levels of $1,2,3,4$, and $5 \%$ on DM basis. The chemical composition of the SA is shown in Table 2. The individual fatty acids ( $\mathrm{g} / 100 \mathrm{~g}$ total fatty acids) of the oil were $5.4 \mathrm{~g}$, C16:0; $4.6 \mathrm{~g}, \mathrm{C} 18: 0 ; 21.0 \mathrm{~g}, \mathrm{C} 18: 1$ and $69.0 \mathrm{~g}, \mathrm{C} 18: 2$.

\subsection{Collecting of inoculum}

Two rumen cannulated Holstein steers $(450 \pm 20 \mathrm{~kg} \mathrm{LW})$, and two rumen cannulated Creole goats ( $50 \pm 2 \mathrm{~kg}$ body weight), were used as the source of the inoculum. The animals were housed in individual pens and fed a diet consisting of oat hay and concentrate (PURINA $^{\circledR}$, Toluca, Mexico) at 60:40 ratio ad libitum, with free access to water. The animals were fed twice at 08:00 and 16:00 h daily and managed under stipulated conditions (Official Mexican
Table 2

Chemical composition of Schizochytrium microalgae.

\begin{tabular}{|c|c|}
\hline Nutrients & $\mathrm{g} / \mathrm{kg}$ dry matter \\
\hline \multicolumn{2}{|c|}{ Proximate composition } \\
\hline Dry matter & 950 \\
\hline Organic matter & 880 \\
\hline Crude fat & 470 \\
\hline Crude protein & 120 \\
\hline Carbohydrates & 180 \\
\hline Crude fiber & 50 \\
\hline \multicolumn{2}{|l|}{ Fatty acids profile ${ }^{a}$} \\
\hline $\mathrm{C} 14: 0$ & 81 \\
\hline $\mathrm{C} 16: 0$ & 256 \\
\hline C20:4 ARA & 23 \\
\hline C20:5 EPA & 23 \\
\hline C22:5 DPA & 168 \\
\hline C22:6 DHA & 400 \\
\hline Others & 49 \\
\hline \multicolumn{2}{|c|}{ Amino acids profile ${ }^{a}$} \\
\hline Alanine & 54 \\
\hline Arginine & 90 \\
\hline Aspartic acid & 94 \\
\hline Cystine & 15 \\
\hline Glutamic acid & 270 \\
\hline Glycine & 44 \\
\hline Histidine & 16 \\
\hline Isoleucine & 27 \\
\hline Leucine & 52 \\
\hline Lysine & 32 \\
\hline Methionine & 17 \\
\hline Phenylalanine & 32 \\
\hline Proline & 35 \\
\hline Serine & 43 \\
\hline Threonine & 40 \\
\hline Tyrosine & 21 \\
\hline Valine & 57 \\
\hline Others & 61 \\
\hline
\end{tabular}

a Provided by the manufacture, Xuhuang Bio-Tech Co., Ltd., Shaanxi, China.

Standard of technical specifications for the production, care and use of laboratory animals, NOM-062-ZOO-1999). Plastic thermos flasks preheated at $39{ }^{\circ} \mathrm{C}$ and flushed with $\mathrm{CO}_{2}$ were used to collect the rumen contents and then transported to the laboratory. The rumen contents were mixed and strained through four layers of cheesecloth into a flask with $\mathrm{O}_{2}$-free headspace. Subsequently, the rumen contents were maintained at a temperature of $39{ }^{\circ} \mathrm{C}$ with a continuous flow of $\mathrm{CO}_{2}$.

\subsection{In vitro incubation process}

The medium used for the incubations contained buffer, macromineral, micromineral, resarzurin solutions and distilled water (Goering and Van Soest, 1970). All the contents were mixed in a volumetric flask using a magnetic stirrer set at $39^{\circ} \mathrm{C}$. Consequently, the ruminal inoculum and the reducing solution were mixed at the ratio of $1: 4(\mathrm{v} / \mathrm{v}) .50 \mathrm{~mL}$ of the prepared rumen liquor plus buffer were poured over $0.5 \mathrm{~g}$ of substrate in $120-\mathrm{mL}$ serum bottles with

Table 1

The composition of total mixed ration.

\begin{tabular}{|c|c|c|c|}
\hline \multicolumn{2}{|l|}{ Ingredient } & \multicolumn{2}{|l|}{ Chemical composition } \\
\hline Material & $\mathrm{g} / \mathrm{kg}$ dry matter & Composition & $\mathrm{g} / \mathrm{kg}$ dry matter \\
\hline Alfalfa hay (Medicago sativa) & 400 & Dry matter & 880 (wet weight basis) \\
\hline Crushed yellow corn & 250 & Organic matter & 934 \\
\hline Soybean meal & 250 & Crude protein & 218 \\
\hline \multirow[t]{2}{*}{ Wheat bran } & 100 & Neutral detergent fiber & 219 \\
\hline & & Acid detergent fiber & 201 \\
\hline
\end{tabular}


appropriate addition of the additives (i.e., SA, SO or a mixture of SA and $\mathrm{SO} / \mathrm{g}$ DM. Bottles were maintained at constant $\mathrm{CO}_{2}$ flow for $30 \mathrm{~s}$, capped with neoprene plugs and sealed with aluminum rings. The vials were placed in an incubator (Riossa ${ }^{\circledR}$, F-51 D, Mexico State, Mexico) at $39{ }^{\circ} \mathrm{C}$ for $48 \mathrm{~h}$. Additionally, three bottles as blanks (rumen fluid only) were incubated for $48 \mathrm{~h}$. Three incubation runs were performed in three weeks.

\subsection{Measurement of biogas production}

The readings of biogas production (GP) were recorded at 2, 4, 6, $8,10,12,24$ and $48 \mathrm{~h}$ of incubation using a water displacement apparatus (Fedorak and Hrudey, 1983). The apparatus was designed with a universal support, with a conical funnel, a $100 \mathrm{~mL}$ burette and two latex hoses of 0.5 ( $1 \mathrm{~m}$ in length and 3/8-inch diameter). The vials were punctured with a 16-gauge needle placed at the end of the hose and the volume of GP (mL) was measured.

After $48 \mathrm{~h}$ of incubation, $5 \mathrm{ml}$ of gas was taken and stored in vials with saturated saline solution prepared with $400 \mathrm{~g}$ of $\mathrm{NaCl}$ in $1 \mathrm{~L}$ of distilled water and the $\mathrm{pH}$ set at 2 . Subsequently, $5 \mathrm{~mL}$ of $20 \%$ methyl orange was added as indicator for $\mathrm{CH}_{4}$ and $\mathrm{CO}_{2}$ concentration determinations. The previously prepared saturated saline solution was stored in $60 \mathrm{~mL}$ serological vials without headspace and neoprene plugs placed and sealed with aluminum rings, and stored away from light.

To determine the $\mathrm{CH}_{4}$ and $\mathrm{CO}_{2}$, a sample of gas phase $(10 \mu \mathrm{L})$ was taken from the vials with saturated saline and injected into a PerkinElmer, Claurus 500 gas chromatograph (Mexico City, Mexico) with a flame ionization detection and helium as the carrier gas. A thermal conductivity detector was used with the oven, column and TCD temperatures programmed at $80{ }^{\circ} \mathrm{C}, 170{ }^{\circ} \mathrm{C}$ and $130{ }^{\circ} \mathrm{C}$, respectively. Retention times were $0.73 \mathrm{~min}$ and 1.05 min for $\mathrm{CH}_{4}$ and $\mathrm{CO}_{2}$, respectively.

At the end of incubation at $48 \mathrm{~h}$, the fermentation process was stopped by swirling the bottles in ice for $5 \mathrm{~min}$ and then the bottles uncapped and the $\mathrm{pH}$ measured immediately using a $\mathrm{pH}$ meter (Thermo Scientific, Orion Star ${ }^{\mathrm{TM}}$ A121, Beverly, MA, USA). The bottles' contents were filtered in to Ankom ${ }^{\mathbb{R}}$ Technologies F57 bags (at constant weight) using a filtration system connected to a vacuum pump. Hot water was used to rinse the bottles three times to ensure recovery of all the residue of fermentation and then the bags dried in a forced air oven $\left(55^{\circ} \mathrm{C}\right.$ for $\left.48 \mathrm{~h}\right)$. Dry matter (DM) degradation was calculated by difference between the initial weight of the dried substrate and the weight of the dried residue.

After the $\mathrm{pH}$ measurement and filtration, $4 \mathrm{~mL}$ of the medium was mixed with $1 \mathrm{~mL}$ of metaphosphoric acid (25\%), and another $4 \mathrm{~mL}$ mixed with $1 \mathrm{~mL}$ of formaldehyde (10\%), shaken slightly and placed in a refrigerator at $4{ }^{\circ} \mathrm{C}$ until analysis of ammonia- $\mathrm{N}$ concentration and bacterial and protozoal count, respectively.

\subsection{Counting of total bacteria and protozoa}

A Petroff-Hausser counting chamber (Hausser Scientific ${ }^{\circledR}, 3900$, Horsham, PA) and a phase contrast microscope (100x, Olympus ${ }^{\circledR}$, BX51, Mexico City, Mexico) were used to quantify the concentration of total bacteria after $48 \mathrm{~h}$ of incubation. $0.5 \mathrm{~mL}$ of $10 \%$ formaldehyde fixed medium was taken and diluted in $4.5 \mathrm{~mL}$ of distilled water. The bacterial concentration per $\mathrm{mL}$ was determined as the average number of bacteria observed in each grid, multiplied by the dilution factor and the chamber factor $\left(2 \times 10^{7}\right)$, according to the following formula:

Bacterial number number $/ \mathrm{mL}=\mu \times \mathrm{FD} 1 \times \mathrm{FD} 2 \times 2^{7}$

where: $\mu$ is the average number of bacteria in each grid per treatment, FD1 is the first dilution factor (1.25) and FD2 is the second dilution factor (10).

For the protozoal count, $1 \mathrm{~mL}$ of the $10 \%$ formaldehyde fixed sample was diluted in $1 \mathrm{~mL}$ of distilled water, then $0.5 \mathrm{~mL}$ of the mixture was taken with a Pasteur pipette (BRAND, 7712, Wertheim, Germany) and deposited into a Neubauer chamber (BRAND, 717810 , Wertheim, Germany), and subsequently observed under a contrast microscope $\left(400 \times\right.$, Carl Zeiss ${ }^{\circledR}$, Axiostar, Mexico City, Mexico). The protozoa count was made in eight quadrants (4 of each grid), taking as viable protozoa those that maintained their morphological integrity. The concentration of protozoa per $\mathrm{mL}$ of culture medium was estimated as the average number of protozoa observed in each grid, multiplied by the dilution factor and the chamber factor $\left(1 \times 10^{4}\right)$, according to the formula:

Protozoal number $=\mu \times$ FD1 $\times$ FD2 $\times 10^{4}$

where: $=\mu$ is the average number of protozoa in each grid per treatment, FD1 is the first dilution factor (5), and FD2 is the second dilution factor (3).

\subsection{Chemical analyses}

Table 3 presents the chemical analysis methods used for the total mixed ration and microalgae. The fatty and amino acid content of SA were determined according to the Chinese national standard methods (National Standards of People's Republic of China 2010) using the analysis methods (method ID: GB 5413.27-2010) and (method ID: GB/T 5009·124-2003), respectively. The SO fatty acid contents were analyzed according to AOAC (1997) using fatty acids methyl esters prepared by base-catalyzed methanolysis of the glycerides as provided by Xuhuang Bio-Tech Co., Ltd., Shaanxi, China. The concentration of ruminal ammonia-N was determined according to Broderick and Kang (1980) method.

\subsection{Calculations}

For the estimation of GP, gas volumes (mL/g DM) were fitted using the NLIN procedure of SAS (2002) according to France et al. (2000) model as:

$y=b \times\left[1-e^{-c(t-L a g)}\right]$

where $y$ is the volume of GP at time $t(h)$; $b$ is the asymptotic GP $(\mathrm{mL} / \mathrm{g} \mathrm{DM}) ; \mathrm{c}$ is the fractional rate of fermentation $(/ \mathrm{h})$, and $\mathrm{L}(\mathrm{h})$ is the discrete lag time prior to any gas is released.

Metabolizable energy (ME, MJ/kg DM) and in vitro organic matter digestibility (OMD, $\mathrm{g} / \mathrm{kg} \mathrm{DM}$ ) were estimated according to Menke et al. (1979) as:

$M E=2.20+0.136 G P+0.057 C P$

where GP is gas production ( $\mathrm{mL} / 0.5 \mathrm{~g} \mathrm{DM})$ and $\mathrm{CP}$ is crude protein

Table 3

Chemical analyses methods used for analyzing the total mixed ration.

\begin{tabular}{ll}
\hline Chemical parameter & Method \\
\hline Dry matter content & (AOAC, 1997; \#934.01) \\
Ash content & (AOAC, 1997; \#942.05) \\
Nitrogen content & (AOAC, 1997; \#954.01) \\
Ether extract & (AOAC, 1997; \#920.39) \\
Neutral detergent fiber & (Van Soest et al., 1991) \\
Acid detergent fiber & (AOAC, 1997; \#973.18) \\
Acid detergent lignin & (AOAC, 1997; \#973.18) \\
\hline
\end{tabular}


$(\mathrm{g} / \mathrm{kg} \mathrm{DM})$

$O M D=148.8+8.89 G P+4.5 C P+0.651 A$

where GP is net GP in $\mathrm{mL}$ from $200 \mathrm{mg}$ of dry sample after $24 \mathrm{~h}$ of incubation, CP is crude protein $(\mathrm{g} / \mathrm{kg} \mathrm{DM})$ and $\mathrm{A}$ is ash $(\mathrm{g} / \mathrm{kg} \mathrm{DM})$.

The partitioning factor at $24 \mathrm{~h}$ of incubation $\left(\mathrm{PF}_{24}\right.$; a measure of fermentation efficiency) was calculated as the ratio of DM degradability in vitro (DMD, $\mathrm{mg}$ ) to the volume $(\mathrm{mL})$ of GP at $24 \mathrm{~h}$ (i.e., $\mathrm{DMD} /$ total GP $\left(\mathrm{GP}_{24}\right)$ ) according to Blümmel et al. (1997). Gas yield $\left(\mathrm{GY}_{24}\right)$ was calculated as the volume of gas $(\mathrm{V}, \mathrm{mL}$ gas/g $\mathrm{DM})$ produced after $24 \mathrm{~h}$ of incubation divided by the amount of DMD $(\mathrm{m}, \mathrm{g})$ as:

$G Y_{24}=\frac{V}{m}$

Short chain fatty acid concentrations (SCFA, mmol/200 mg DM) were calculated according to Getachew et al. (2002) as:

$\mathrm{SCFA}=0.0222 \mathrm{GP}-0.00425$

where GP is the $24 \mathrm{~h}$ net GP (mL/200 $\mathrm{mg} \mathrm{DM})$.

Microbial biomass production (MCP, $\mathrm{mg} / \mathrm{g}$ DM) was calculated (Blümmel et al., 1997) as:

$\mathrm{MCP}=m-($ gas $\times 2.2)$

where the $2.2(\mathrm{mg} / \mathrm{mL})$ is a stoichiometric factor that expresses $\mathrm{mg}$ of $\mathrm{C}, \mathrm{H}$ and $\mathrm{O}$ required for the SCFA gas associated with production of $1 \mathrm{~mL}$ of gas (Blümmel et al., 1997) and gas is gas (mL).

\subsection{Statistical analyses}

The effects of additive type, inoculum source and additive dose were analyzed using a $3 \times 4$ factorial design with 3 replicates in a randomized complete block design. Data were analyzed using the GLM procedure (SAS, 2002) using the model: $Y_{i j k l}=\mu+A_{i}+R_{j}$ $+D_{k}+(A \times R)_{i j}+(A \times D)_{i k}+(R \times D)_{j k}+(A \times R \times D)_{i j k}+\varepsilon_{i j k l}$ where: $Y_{\mathrm{ijkl}}$ is the observation, $\mu$ is the population mean, $A_{\mathrm{i}}$ is the additive type effect, $R_{j}$ is the inoculum source effect, $D_{k}$ is the additive dose effect, $(A \times R)_{i j}$ is the interaction between additive type and inoculum source, $(A \times R \times D)_{i j k}$ is the interaction between additive type, inoculum source and additive dose, and $\varepsilon_{\mathrm{ijkl}}$ is the residual error. Tukey test was used to separate means.

\section{Results and discussion}

The occurrence of interactions between inoculum source $\times$ additive type, and inoculum source $\times$ additive type $\times$ dose are evidences that the effect of each additive was inoculum and dose-dependent. Therefore, the discussion will be based on the effect of each feed additive at different doses with both rumen inoculum sources.

\subsection{Biogases production}

Significant effects $(P<0.05)$ of inoculum source $\times$ additive type, and inoculum source $\times$ additive type $\times$ dose interactions were observed for GP, $\mathrm{CH}_{4}$ and $\mathrm{CO}_{2}$ production (Table 4 ). The goat inoculum at levels $1,2,4$, and $5 \%$ of SO, the doses 2,3 and $5 \%$ of SA and the doses 1 and $3 \%$ of SASO increased $(P<0.001)$ the asymptotic GP, and GP, while decreasing $(P<0.05)$ the rate of GP compared with the control treatment. The steer inoculum at doses 1 and $4 \%$ of SO increased $(P<0.001)$ the asymptotic GP and the rate of GP, while all levels of SA and SASO treatments decreased the asymptotic GP and increased the rate of GP. All doses of additives linearly decreased $(P<0.001)$ lag time of GP with the steers inoculum whereas the goat inoculum had no effect on lag time of GP.

At the levels of $3 \%$ of SO, 1 and $4 \%$ of SA and 2,4 and $5 \%$ of SASO, the goats' inoculum decreased $\mathrm{CH}_{4}$ production $(P<0.001)$, while the other levels of additives increased it (Table 4). All doses of SO decreased $(P<0.005)$ proportional $\mathrm{CH}_{4}$ production, and increased proportional $\mathrm{CO}_{2}$ production. Without affecting the proportional $\mathrm{CH}_{4}$ production, $\mathrm{SO}$ at 2,3 and $5 \%$, and all levels of both SA and SASO decreased $\mathrm{CH}_{4}$ production $(P=0.001)$ with the steers inoculum. The levels 3 and $5 \%$ of SO increased the production of $\mathrm{CO}_{2}$ without affecting the proportional $\mathrm{CO}_{2}$ production and $\mathrm{CO}_{2}$ production.

It has been previously reported that using rumen fluid from different ruminant species to inoculate the in vitro incubation cultures is a useful tool to examine possible differences in the ruminal microbial population and the digestive capacity of each ruminant species (Salem, 2005; Weimer, 2015). The lack of effect on asymptotic GP with cattle and goat inoculums is in agreement with earlier works by Aderinboye et al. (2016) who reported similarity in the estimated total GP among inoculums collected from cattle, sheep and goats. In the present experiment, the rate of GP was higher for goat than steer inoculum. In contrast, Aderinboye et al. (2016) observed higher rate of GP with cattle compared with goat inoculum, which might be due to the varied diets fed to rumen liquor donors. Cone et al. (2000) reported a well-correlated total GP from inoculum of sheep and cattle, but poor correlation of rates of GP with the two inoculums. At the same time, the lack of effect on lag time between steer and goat inoculum in the current study reveals that the time taken for microbes to adhere to the substrates, and microbial attachment to insoluble substrate was similar.

Sunflower oil at all levels produced higher GP with increasing rate of GP with goat inoculum whereas with the steer inoculum, SO only caused the same effect at two levels (i.e., 1 and 4\%) - Fig. 1. The reasons for these difference between inoculum from goats and steers are unclear, however, the differences in lipid metabolism among ruminant species (Chilliard et al., 2003) is a probable reason. It was expected that increasing the level of SO would disturb fermentation and digestion activities of the total mixed ration due to the anti-microbial effect of UFA of the oil. Additionally, the inclusion of SO up to 4 and 5\% of the diet did not negatively affect ruminal fermentation. In agreement with results of the current study, Narimani-Rad et al. (2011) observed a positive effect with the inclusion $\mathrm{SO}$ at $2.5 \%$ to a concentrate-based diet containing alfalfa forage and barley grain at 40:60, and a negative effect on GP at 5\% of SO inclusion. Furthermore, Narimani-Rad et al. (2012) observed lack of effect on GP or rate of GP with the inclusion of SO at the same levels with forage-based diets. This variation might be due to the different substrates used. Sunflower oil inclusion to a foragebased diet may coated feed particles and decreased attachment of ruminal microbes resulting in similar fermentation patterns (Narimani-Rad et al., 2012).

The in vitro results of micro-algae supplementation appear promising, in agreement with Kholif et al. (2017), however, further in vivo studies are required to elucidate the optimum dose in ruminants in terms of effects on feed nutritive value and $\mathrm{CH}_{4}$ production. Schizochytrium microalgae alone or with SO (i.e., SASO treatment) negatively affected GP with steer inoculum revealing negative effects on steers' nutrition; however, some doses increased GP with goat inoculum. More research is required to elucidate the effect of SA on feed utilization between goats and steers. This difference is another indicator about different microbial profile between goats and steers. It is well documented that most species of microalgae contain some antioxidative, antimicrobial or compounds with cytotoxic effects (Scholz and Liebezeit, 2012), which might be negatively affected GP. Furthermore, the contents 
Table 4

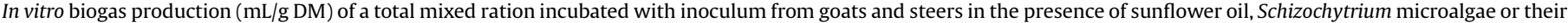
mixture at 1:1 DM basis.

\begin{tabular}{|c|c|c|c|c|c|c|c|c|c|c|c|c|}
\hline \multicolumn{2}{|c|}{ Inoculum Additive } & \multirow{2}{*}{$\begin{array}{l}\text { Dose (\% of } \\
\text { ration } \mathrm{DM})\end{array}$} & \multicolumn{4}{|c|}{ Gas production parameters ${ }^{\mathrm{a}}$} & \multicolumn{3}{|c|}{$\mathrm{CO}_{2}$ production at $48 \mathrm{~h}$ of incubation } & \multicolumn{3}{|c|}{$\mathrm{CH}_{4}$ production at $48 \mathrm{~h}$ of incubation } \\
\hline & & & $b$ & $c$ & Lag & $\begin{array}{l}\mathrm{mL} \text { gas } / \mathrm{g} \\
\text { degraded } \\
\mathrm{DM}\end{array}$ & $\begin{array}{l}\mathrm{CO}_{2} \\
\text { production }\end{array}$ & $\begin{array}{l}\text { Proportional } \\
\mathrm{CO}_{2} \\
\text { production }\end{array}$ & $\begin{array}{l}\mathrm{mL} \mathrm{CO}_{2} / \mathrm{g} \\
\text { degraded } \\
\mathrm{DM}\end{array}$ & $\begin{array}{l}\mathrm{CH}_{4} \\
\text { production }\end{array}$ & $\begin{array}{l}\text { Proportional } \\
\mathrm{CH}_{4} \\
\text { production }\end{array}$ & $\begin{array}{l}\mathrm{mL} \mathrm{CH}_{4} / \mathrm{g} \\
\text { degraded } \\
\mathrm{DM}\end{array}$ \\
\hline \multirow[t]{20}{*}{ Goat } & Control & 0 & 192 & 0.125 & 2.31 & 288 & 170 & 89.0 & 257 & 21.1 & 11.0 & 31.8 \\
\hline & Sunflower oil & 1 & 273 & 0.099 & 1.87 & 360 & 232 & 85.8 & 309 & 38.4 & 14.2 & 51.2 \\
\hline & & 2 & 267 & 0.104 & 2.15 & 355 & 223 & 84.1 & 299 & 42.2 & 15.9 & 56.6 \\
\hline & & 3 & 162 & 0.215 & 2.14 & 215 & 135 & 83.5 & 180 & 26.8 & 16.5 & 35.5 \\
\hline & & 4 & 296 & 0.095 & 1.31 & 388 & 248 & 84.9 & 329 & 44.5 & 15.1 & 59.0 \\
\hline & & 5 & 278 & 0.106 & 2.04 & 363 & 224 & 80.9 & 294 & 52.9 & 19.1 & 69.4 \\
\hline & Schizochytrium microalgae & 1 & 154 & 0.214 & 2.44 & 198 & 132 & 85.5 & 170 & 22.4 & 14.5 & 28.8 \\
\hline & & 2 & 277 & 0.100 & 2.10 & 353 & 236 & 86.0 & 304 & 38.5 & 14.0 & 49.5 \\
\hline & & 3 & 270 & 0.111 & 1.98 & 359 & 231 & 86.1 & 309 & 37.4 & 13.9 & 50.0 \\
\hline & & 4 & 163 & 0.223 & 2.84 & 213 & 143 & 87.8 & 187 & 19.8 & 12.2 & 26.0 \\
\hline & & 5 & 248 & 0.114 & 2.08 & 328 & 212 & 85.6 & 281 & 35.6 & 14.4 & 47.1 \\
\hline & Sunflower + Schizochytrium & 1 & 265 & 0.108 & 1.96 & 349 & 232 & 88.3 & 308 & 31.0 & 11.8 & 41.0 \\
\hline & microalgae & 2 & 152 & 0.222 & 2.29 & 202 & 132 & 86.6 & 175 & 20.4 & 13.4 & 27.0 \\
\hline & & 3 & 260 & 0.101 & 1.96 & 338 & 224 & 87.0 & 294 & 33.7 & 13.0 & 44.0 \\
\hline & & 4 & 165 & 0.197 & 2.12 & 220 & 143 & 86.3 & 190 & 22.7 & 13.7 & 30.2 \\
\hline & & 5 & 144 & 0.224 & 2.74 & 193 & 125 & 87.0 & 168 & 18.7 & 13.0 & 25.2 \\
\hline & SEM & & 4.5 & 0.0039 & 0.148 & 7.5 & 4.5 & 1.07 & 7.3 & 2.71 & 1.07 & 3.63 \\
\hline & Additive & & $<0.001$ & $<0.001$ & 0.001 & $<0.001$ & $<0.001$ & 0.538 & $<0.001$ & 0.004 & 0.547 & 0.004 \\
\hline & Linear & & $<0.001$ & $<0.001$ & 0.299 & 0.018 & $<0.001$ & 0.001 & 0.008 & 0.892 & 0.001 & 0.033 \\
\hline & Quadratic & & $<0.001$ & 0.022 & 0.148 & 0.229 & $<0.001$ & 0.005 & 0.016 & 0.168 & 0.006 & 0.015 \\
\hline \multirow[t]{20}{*}{ Steers } & Control & 0 & 235 & 0.093 & 2.12 & 340 & 204 & 87.9 & 299 & 28.0 & 12.1 & 41.0 \\
\hline & Sunflower oil & 1 & 339 & 0.093 & 1.51 & 437 & 286 & 85.1 & 373 & 49.8 & 14.9 & 64.8 \\
\hline & & 2 & 214 & 0.196 & 1.75 & 281 & 181 & 84.7 & 238 & 32.7 & 15.3 & 43.0 \\
\hline & & 3 & 201 & 0.250 & 1.84 & 271 & 167 & 83.4 & 226 & 33.2 & 16.6 & 44.9 \\
\hline & & 4 & 339 & 0.091 & 1.79 & 433 & 272 & 81.4 & 353 & 62.1 & 18.6 & 80.5 \\
\hline & & 5 & 219 & 0.210 & 1.79 & 289 & 176 & 80.3 & 232 & 43.0 & 19.7 & 56.9 \\
\hline & Schizochytrium microalgae & 1 & 192 & 0.249 & 1.84 & 257 & 168 & 87.4 & 225 & 24.1 & 12.6 & 32.1 \\
\hline & & 2 & 221 & 0.189 & 1.73 & 290 & 189 & 85.6 & 248 & 31.9 & 14.4 & 41.7 \\
\hline & & 3 & 210 & 0.210 & 1.77 & 285 & 180 & 85.9 & 245 & 29.7 & 14.1 & 40.3 \\
\hline & & 4 & 201 & 0.197 & 1.64 & 269 & 173 & 86.1 & 231 & 28.0 & 13.9 & 37.6 \\
\hline & & 5 & 197 & 0.207 & 1.79 & 254 & 169 & 85.9 & 218 & 27.9 & 14.1 & 36.0 \\
\hline & Sunflower + Schizochytrium & 1 & 209 & 0.217 & 1.81 & 274 & 180 & 86.0 & 235 & 29.2 & 14.0 & 38.3 \\
\hline & microalgae & 2 & 182 & 0.211 & 1.51 & 240 & 156 & 86.0 & 206 & 25.5 & 14.0 & 33.8 \\
\hline & & 3 & 208 & 0.206 & 1.80 & 271 & 178 & 85.6 & 232 & 30.0 & 14.4 & 39.0 \\
\hline & & 4 & 203 & 0.231 & 1.83 & 264 & 178 & 87.9 & 232 & 24.7 & 12.1 & 32.2 \\
\hline & & 5 & 178 & 0.207 & 1.45 & 232 & 156 & 87.7 & 204 & 21.7 & 12.3 & 28.4 \\
\hline & SEM & & 8.0 & 0.0047 & 0.137 & 12.2 & 7.3 & 1.166 & 11.5 & 3.05 & 1.16 & 4.05 \\
\hline & Additive & & $<0.001$ & $<0.001$ & $<0.001$ & $<0.001$ & $<0.001$ & 0.443 & $<0.001$ & 0.004 & 0.443 & 0.005 \\
\hline & Linear & & $<0.001$ & $<0.001$ & 0.067 & $<0.001$ & $<0.001$ & 0.122 & $<0.001$ & 0.537 & 0.224 & 0.521 \\
\hline & Quadratic & & $<0.001$ & $<0.001$ & $<0.001$ & 0.053 & 0.001 & 0.743 & 0.104 & 0.045 & 0.758 & 0.208 \\
\hline \multicolumn{2}{|c|}{ Pooled SEM ${ }^{\mathrm{b}}$} & & 6.5 & 0.0043 & 0.143 & 10.10 & 6.06 & 1.12 & 9.61 & 2.88 & 1.12 & 3.85 \\
\hline \multicolumn{13}{|c|}{$P$ value } \\
\hline \multicolumn{2}{|c|}{ Inoculum } & & 0.090 & $<0.001$ & 0.387 & 0.260 & 0.019 & 0.035 & 0.082 & 0.282 & 0.034 & 0.161 \\
\hline Addit & & & $<0.001$ & $<0.001$ & $<0.001$ & $<0.001$ & $<0.001$ & 0.326 & $<0.001$ & $<0.001$ & 0.324 & $<0.001$ \\
\hline \multicolumn{13}{|c|}{ 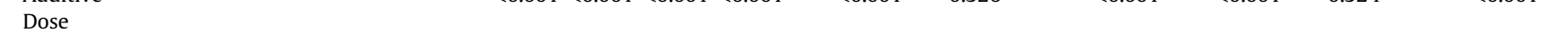 } \\
\hline \multicolumn{2}{|c|}{ Linear } & & 0.156 & $<0.001$ & 0.615 & $<0.001$ & 0.101 & 0.561 & $<0.001$ & 0.709 & 0.549 & 0.054 \\
\hline \multicolumn{2}{|c|}{ Quadratic } & & $<0.001$ & $<0.001$ & $<0.001$ & 0.022 & $<0.001$ & 0.080 & 0.007 & 0.535 & 0.082 & 0.455 \\
\hline \multicolumn{2}{|c|}{ Inoculum $\times$ additive } & & 0.007 & 0.001 & 0.004 & 0.038 & 0.002 & 0.713 & 0.052 & 0.466 & 0.726 & 0.629 \\
\hline \multicolumn{2}{|c|}{ Inoculum $\times$ additive $\times$ dose } & & $<0.001$ & $<0.001$ & $<0.001$ & $<0.001$ & $<0.001$ & 0.483 & $<0.001$ & 0.040 & 0.475 & 0.071 \\
\hline
\end{tabular}

${ }^{a} b$ is the asymptotic gas production ( $\left.\mathrm{mL} / \mathrm{g} \mathrm{DM}\right) ; c$ is the rate of gas production $(/ \mathrm{h})$; Lag is the initial delay before gas production begins (h).

b SEM, standard error of the mean.

of long chain fatty acids in SA may have a negative effect on feed digestion and fermentation (Beauchemin et al., 2007; Burnett et al., 2017).

The different effects of rumen inoculum on $\mathrm{CH}_{4}$ and fermentation parameters could be a result of different bacterial and protozoal populations and microbial activity in goats and steers (Aderinboye et al., 2016). Hook et al. (2010) reported that $\mathrm{CH}_{4}$ production varies based on the ruminant species because the protozoal population varies from animal-to-animal despite the feeding of the same diets (Boeckaert et al., 2007). Ruminal microbial populations depend mainly on the type of diet fed, and since both of steers and goats were maintained on the same diet, microbial species were not expected to vary (Mould et al., 2005).
Other factors such as host animal effects, sampling time and source, sample preparation and inoculation could have caused some variations in inoculum (Mould et al., 2005). Additionally, differences in dentition, chewing/eating behavior, gut physiology, compartment dimensions and retention time would influence gut microflora (Salem et al., 2013). Thus, variations in $\mathrm{CH}_{4}$ production and fermentation parameters between steer and goat rumen fluid indicates that one species cannot be used to predict $\mathrm{CH}_{4}$ production and fermentation profile of feeds (Aderinboye et al., 2016), and wherever possible that the inoculum should be obtained from an appropriate host animal.

Sustainable mitigation of $\mathrm{CH}_{4}$ emissions is not only environmentally beneficial, but would also increase feed energy-use 

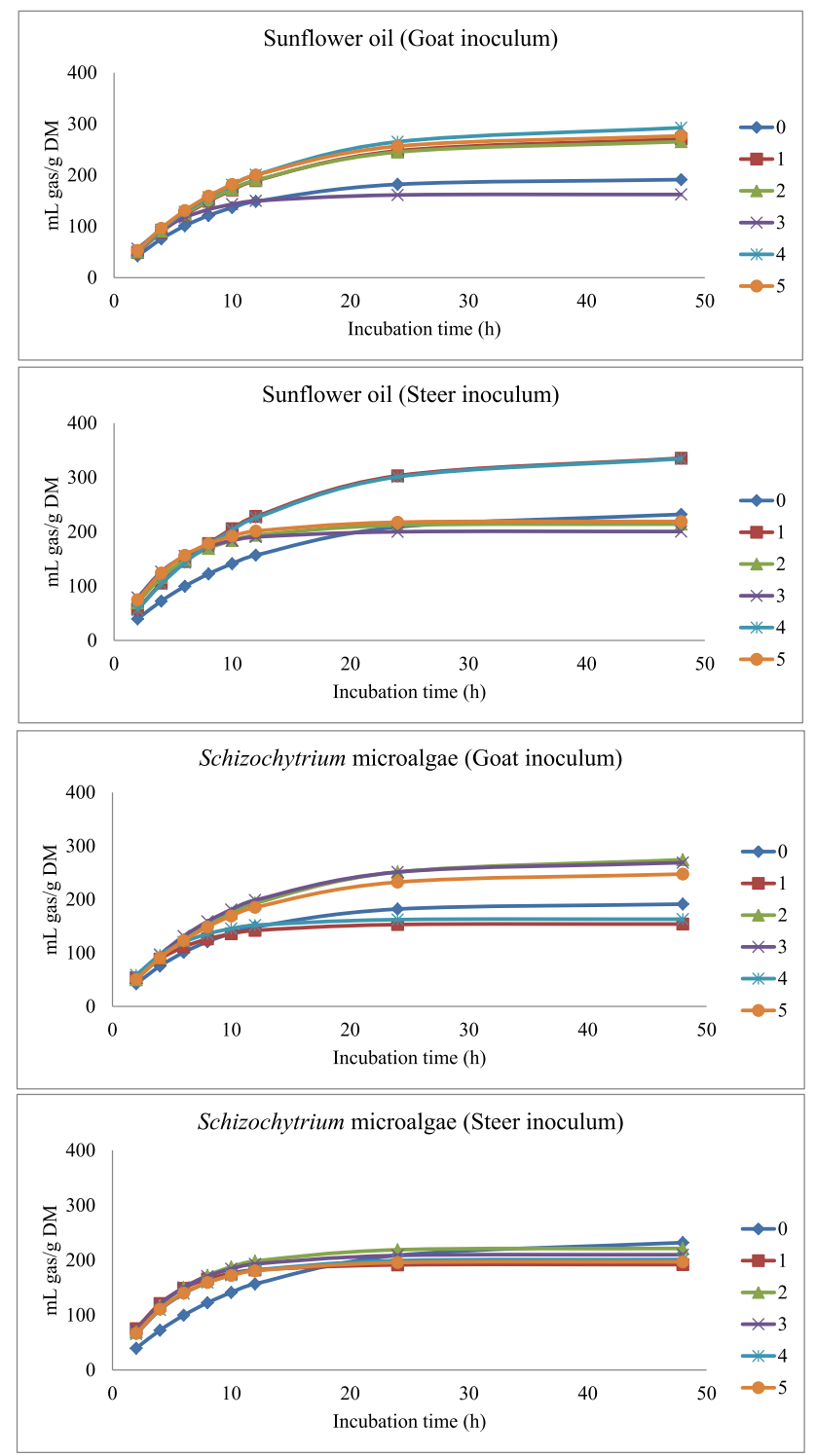

Sunflower oil + Schizochytrium microalgae (Goat inoculum)

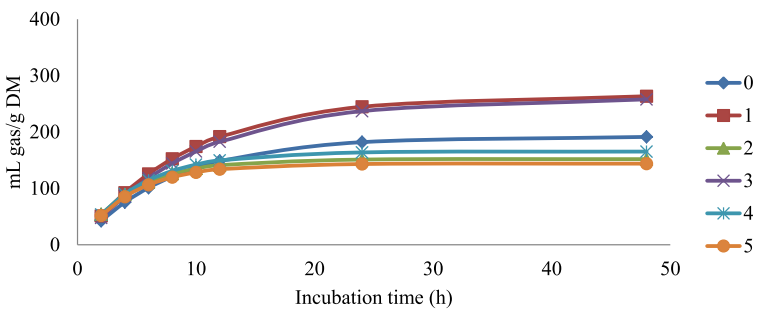

Sunflower oil + Schizochytrium microalgae (Steer inoculum)

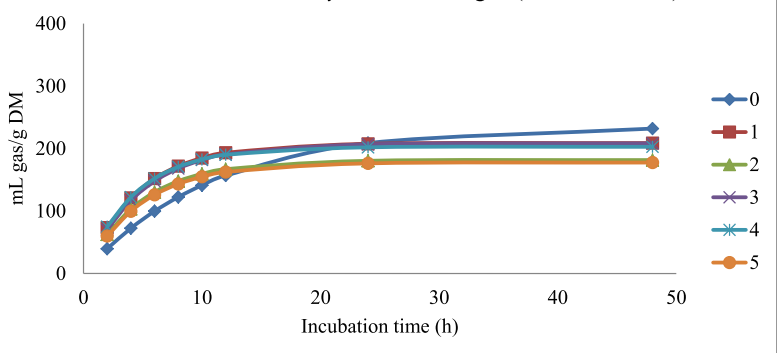

efficiency in ruminants. Based on the energy balances reported by Nkrumah et al. (2006), the reduction in $\mathrm{CH}_{4}$ emission could potentially increase body weight gain of growing cattle by $75 \mathrm{~g} /$ $\mathrm{d}$ and milk production in dairy cows by approximately $1 \mathrm{~L} / \mathrm{d}$. The inclusion of dietary lipids is considered as one of the most effective strategy of depressing ruminal methanogenesis (Martin et al., 2010). However, although high levels of dietary lipids may reduce $\mathrm{CH}_{4}$ production up to $40 \%$ (Jordan et al., 2006), increasing the level of dietary lipids beyond $8 \%$ can reduce feed intake. Therefore, the level of lipids in ruminant diets must be limited to $6-8 \%$ DM to avoid negative impacts on feed intake and fiber digestion and to reduce $\mathrm{CH}_{4}$ production by up to 10-25\% (Beauchemin et al., 2008). In the present experiment, SO, SA and SASO decreased proportional $\mathrm{CH}_{4}$. This result was expected based on the well documented theory that dietary lipids can be used as an option to reduce methanogenic archaea, due to their ability to inhibit ruminal protozoa (Hook et al., 2010). Diets that high in UFA undergo ruminal biohydrogenation, which forms an alternative $\mathrm{H}_{2}$ sink to methanogenesis (Johnson and Johnson, 1995). Reduction of $\mathrm{H}_{2}$ accumulation in the rumen by addition of UFA seems to be a promising procedure to reduce rumen $\mathrm{CH}_{4}$ production. Fatty acids can bind to the cell membrane and interrupt membrane transport (Dohme et al., 2001). Suppression of ruminal methanogenesis with dietary lipids depends mainly on the degree of unsaturation of the fatty acids, where sources rich in long chain fatty acids inhibit ruminal cellulolytic microbes to a greater degree than SCFA (Meale et al., 2012). This may explain the varied responses between SO and SA.

Microalgae with high concentrations of EPA and DHA fatty acids have been shown to shift ruminal fermentation towards increased propionate production and decreased $\mathrm{CH}_{4}$ production (Johnson and Johnson, 1995). Fievez et al. (2007) reported a reduction on in vitro $\mathrm{CH}_{4}$ production up to $80 \%$ with the addition of DHA-enriched microalgae.

The varied responses to SO and SA inclusion between goat and steer inoculum were expected because many factors including the ruminant species, experimental diet, and the type of lipid used accounted for varying effects of lipids on methane abatement (Hook et al., 2010). Beauchemin et al. (2007) reported an $11.5-22.0 \%$ reduction in methanogenesis with the inclusion of SO in the diet of cows.

\subsection{Ruminal bacteria and protozoa count}

There were no significant statistical differences $(P>0.05)$ with the inoculum source $\times$ additive type or inoculum source $\times$ additive type $\times$ dose interactions for bacterial and protozoal counts (Table 5). Both inoculum sources and additives at all doses quadratically decreased $(P=0.003)$ total protozoal counts and linearly increased $(P=0.002)$ total bacterial counts.

Different effects on ruminal protozoa with different dietary fat sources have been reported (Wanapat and Khampa, 2006; Abubakr et al., 2013). The lower protozoal counts with SO and SA can be explained based on the toxic effect of oils at high levels (Abubakr et al., 2013) and unsaturated C18 fatty acids (i.e., SO; Newbold and Chamberlain, 1988) to rumen ciliate protozoa. High level of dietary lipid is toxic to rumen protozoa due to the limited ability of protozoa to absorb and transform lipids (Williams, 1989), resulting in rupture of the protozoa cells (Girard and Hawke, 1978). Protozoa has a low ability to perform ruminal fat biohydrogenation compared with bacteria, thus the inclusion of dietary lipids in the

Fig. 1. In vitro biogas production $(\mathrm{mL} / \mathrm{g}$ incubated $\mathrm{DM})$ of a total mixed ration incubated with inoculum from goats and steers in the presence of sunflower oil, Schizochytrium microalgae or their mixture (1:1 DM basis) at five levels. 
Table 5

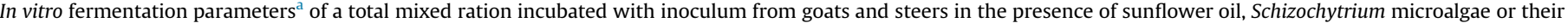
mixture at 1:1 DM basis.

\begin{tabular}{|c|c|c|c|c|c|c|c|c|c|c|c|c|c|}
\hline \multicolumn{2}{|c|}{ Inoculum Additive } & \multirow{2}{*}{$\begin{array}{l}\text { Dose (\% of ration } \\
\text { DM) } \\
0\end{array}$} & \multirow{2}{*}{$\begin{array}{l}\mathrm{pH} \\
6.91\end{array}$} & \multirow{2}{*}{$\begin{array}{l}\text { SCFA } \\
4.02\end{array}$} & \multirow{2}{*}{$\begin{array}{l}\mathrm{NH}_{3}-\mathrm{N} \\
55.7\end{array}$} & \multirow{2}{*}{$\begin{array}{l}\text { DMD } \\
664\end{array}$} & \multirow{2}{*}{\begin{tabular}{|l} 
OMD \\
575
\end{tabular}} & \multirow{2}{*}{$\begin{array}{l}\text { ME } \\
8.39\end{array}$} & \multirow{2}{*}{$\begin{array}{l}\mathrm{PF}_{24} \\
5.59\end{array}$} & \multirow{2}{*}{$\begin{array}{c}\mathrm{GY}_{24} \\
179\end{array}$} & \multirow{2}{*}{$\begin{array}{l}\text { MCP } \\
616\end{array}$} & \multirow{2}{*}{$\begin{array}{l}\begin{array}{l}\text { Total } \\
\text { bacteria } \times 10^{8}\end{array} \\
4.88\end{array}$} & \multirow{2}{*}{$\begin{array}{l}\begin{array}{l}\text { Total } \\
\text { protozoa } \times 10^{5}\end{array} \\
6.82\end{array}$} \\
\hline Goat & Control & & & & & & & & & & & & \\
\hline & Sunflower oil & 1 & 6.49 & 5.47 & 66.4 & 753 & 691 & 10.17 & 5.18 & 193 & 739 & 9.73 & 4.36 \\
\hline & & 2 & 6.49 & 5.42 & 61.9 & 747 & 687 & 10.11 & 5.19 & 192 & 734 & 10.58 & 3.75 \\
\hline & & 3 & 6.44 & 3.56 & 60.3 & 755 & 538 & 7.83 & 5.78 & 173 & 578 & 11.97 & 3.09 \\
\hline & & 4 & 6.46 & 5.86 & 61.7 & 755 & 723 & 10.66 & 5.11 & 196 & 772 & 11.72 & 3.72 \\
\hline & & 5 & 6.46 & 5.67 & 61.6 & 762 & 707 & 10.42 & 5.14 & 194 & 756 & 9.60 & 4.49 \\
\hline & Schizochytrium microalgae & 1 & 6.45 & 3.38 & 61.5 & 776 & 524 & 7.61 & 5.88 & 170 & 562 & 4.98 & 4.39 \\
\hline & & 2 & 6.47 & 5.56 & 61.3 & 776 & 698 & 10.28 & 5.17 & 194 & 746 & 8.92 & 4.30 \\
\hline & & 3 & 6.47 & 5.55 & 60.4 & 749 & 698 & 10.28 & 5.17 & 193 & 746 & 8.95 & 3.74 \\
\hline & & 4 & 6.48 & 3.58 & 61.7 & 765 & 540 & 7.86 & 5.77 & 173 & 580 & 7.28 & 4.22 \\
\hline & & 5 & 6.48 & 5.14 & 69.7 & 754 & 664 & 9.76 & 5.26 & 190 & 711 & 9.48 & 4.13 \\
\hline & Sunflower + Schizochytrium & 1 & 6.46 & 5.41 & 56.3 & 755 & 686 & 10.10 & 5.20 & 192 & 734 & 9.05 & 3.78 \\
\hline & microalgae & 2 & 6.40 & 3.33 & 56.4 & 754 & 520 & 7.55 & 5.90 & 170 & 559 & 11.17 & 3.54 \\
\hline & & 3 & 6.48 & 5.24 & 58.7 & 764 & 673 & 9.89 & 5.23 & 191 & 719 & 12.55 & 3.81 \\
\hline & & 4 & 6.43 & 3.62 & 58.1 & 750 & 543 & 7.90 & 5.75 & 174 & 582 & 8.97 & 3.41 \\
\hline & & 5 & 6.38 & 3.16 & 60.1 & 744 & 506 & 7.34 & 6.01 & 167 & 544 & 10.30 & 3.79 \\
\hline & SEM & & 0.009 & 0.091 & 0.91 & 9.9 & 7.3 & 0.111 & 0.038 & 1.1 & 7.6 & 1.626 & 0.661 \\
\hline & Additive & & $<0.001$ & $<0.001$ & $<0.001$ & 0.023 & $<0.001$ & $<0.001$ & $<0.001$ & $<0.001$ & $<0.001$ & 0.003 & 0.048 \\
\hline & Linear & & $<0.001$ & $<0.001$ & $<0.001$ & $<0.001$ & $<0.001$ & $<0.001$ & $<0.001$ & $<0.001$ & $<0.001$ & 0.930 & 0.006 \\
\hline & Quadratic & & $<0.001$ & $<0.001$ & $<0.001$ & $<0.001$ & $<0.001$ & $<0.001$ & $<0.001$ & 0.0005 & $<0.001$ & 0.041 & 0.007 \\
\hline \multirow[t]{20}{*}{ Steers } & Control & 0 & 6.96 & 4.61 & 55.7 & 683 & 622 & 9.12 & 5.40 & 185 & 666 & 4.26 & 6.23 \\
\hline & Sunflower oil & 1 & 6.52 & 6.71 & 62.3 & 767 & 790 & 11.69 & 4.98 & 201 & 843 & 12.22 & 3.05 \\
\hline & & 2 & 6.51 & 4.69 & 61.3 & 761 & 628 & 9.21 & 5.37 & 186 & 673 & 11.82 & 4.20 \\
\hline & & 3 & 6.47 & 4.42 & 65.6 & 740 & 607 & 8.88 & 5.45 & 183 & 650 & 10.72 & 3.24 \\
\hline & & 4 & 6.47 & 6.66 & 62.9 & 772 & 786 & 11.63 & 4.99 & 200 & 839 & 7.57 & 4.35 \\
\hline & & 5 & 6.47 & 4.81 & 62.2 & 757 & 638 & 9.36 & 5.34 & 187 & 683 & 8.95 & 4.06 \\
\hline & Schizochytrium microalgae & 1 & 6.47 & 4.23 & 63.0 & 748 & 592 & 8.65 & 5.52 & 181 & 634 & 7.45 & 2.28 \\
\hline & & 2 & 6.47 & 4.84 & 61.7 & 764 & 641 & 9.40 & 5.33 & 188 & 686 & 6.13 & 4.76 \\
\hline & & 3 & 6.50 & 4.61 & 61.8 & 737 & 622 & 9.12 & 5.39 & 185 & 666 & 8.10 & 2.95 \\
\hline & & 4 & 6.49 & 4.40 & 70.0 & 749 & 606 & 8.86 & 5.46 & 183 & 649 & 8.13 & 4.71 \\
\hline & & 5 & 6.48 & 4.32 & 65.5 & 776 & 599 & 8.77 & 5.48 & 182 & 642 & 9.88 & 2.54 \\
\hline & Sunflower + Schizochytrium & 1 & 6.47 & 4.59 & 57.9 & 763 & 620 & 9.09 & 5.40 & 185 & 664 & 7.22 & 3.08 \\
\hline & microalgae & 2 & 6.42 & 3.98 & 59.0 & 756 & 572 & 8.35 & 5.61 & 178 & 613 & 11.05 & 3.30 \\
\hline & & 3 & 6.49 & 4.57 & 58.5 & 768 & 619 & 9.07 & 5.41 & 185 & 663 & 9.00 & 3.15 \\
\hline & & 4 & 6.45 & 4.46 & 61.5 & 767 & 610 & 8.94 & 5.44 & 184 & 654 & 11.50 & 3.53 \\
\hline & & 5 & 6.41 & 3.89 & 60.6 & 766 & 565 & 8.24 & 5.64 & 177 & 606 & 10.08 & 4.38 \\
\hline & SEM & & 0.016 & 0.139 & 1.03 & 9.6 & 11.1 & 0.170 & 0.039 & 1.3 & 11.7 & 1.718 & 0.541 \\
\hline & Additive & & 0.002 & $<0.001$ & $<0.001$ & 0.038 & $<0.001$ & $<0.001$ & $<0.001$ & $<0.001$ & $<0.001$ & 0.006 & 0.049 \\
\hline & Linear & & $<0.001$ & 0.338 & $<0.001$ & $<0.001$ & 0.340 & 0.347 & 0.231 & 0.244 & 0.339 & 0.561 & 0.854 \\
\hline & Quadratic & & $<0.001$ & $<0.001$ & 0.003 & $<0.001$ & $<0.001$ & $<0.001$ & 0.001 & $<0.001$ & $<0.001$ & 0.023 & 0.003 \\
\hline \multicolumn{2}{|c|}{ Pooled SEM ${ }^{\mathrm{b}}$} & & 0.013 & 0.117 & 0.973 & 9.7 & 9.4 & 0.144 & 0.039 & 1.2 & 9.9 & 1.672 & 0.604 \\
\hline \multicolumn{14}{|c|}{$P$ value } \\
\hline \multicolumn{2}{|c|}{ Inoculum } & & $<0.001$ & $<0.001$ & 0.1452 & 0.1413 & $<0.001$ & $<0.001$ & $<0.001$ & $<0.001$ & $<0.001$ & 0.022 & 0.037 \\
\hline Addi & & & $<0.001$ & $<0.001$ & $<0.001$ & 0.8433 & $<0.001$ & $<0.001$ & $<0.001$ & $<0.001$ & $<0.001$ & $<0.001$ & 0.027 \\
\hline Dose & & & & & & & & & & & & & \\
\hline Lin & & & $<0.001$ & $<0.001$ & $<0.001$ & $<0.001$ & $<0.001$ & $<0.001$ & $<0.001$ & 0.008 & $<0.001$ & 0.716 & 0.003 \\
\hline $\mathrm{Qu}$ & Iratic & & $<0.001$ & $<0.001$ & $<0.001$ & $<0.001$ & $<0.001$ & $<0.001$ & $<0.001$ & $<0.001$ & $<0.001$ & 0.002 & 0.881 \\
\hline Inocl & $\mathrm{Im} \times$ additive & & 0.715 & 0.001 & 0.001 & 0.103 & 0.001 & 0.001 & 0.021 & 0.0197 & 0.001 & 0.223 & 0.174 \\
\hline Inocl & $\mathrm{Im} \times$ additive $\times$ dose & & 0.981 & $<0.001$ & $<0.001$ & 0.453 & $<0.001$ & $<0.001$ & $<0.001$ & $<0.001$ & $<0.001$ & 0.677 & 0.535 \\
\hline
\end{tabular}

a DMD is dry matter degradability (mg/g DM), $\mathrm{GY}_{24}$ is gas yield at $24 \mathrm{~h}$ (mL gas/g DMD), MCP is microbial protein production ( $\mathrm{mg} / \mathrm{g}$ DM), $\mathrm{ME}$ is metabolizable energy (MJ/kg

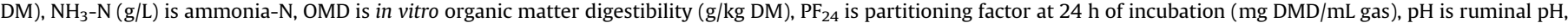
SCFA is short-chain fatty acids ( $\mathrm{mmol} / \mathrm{g} \mathrm{DM})$.

b SEM, standard error of the mean.

diet decreased the protozoal growth. Boeckaert et al. (2007) showed a decreased importance of Isotricha prostoma and Isotricha intestinalis and some species of Epidinium caudatum ciliates in the rumen of SA-fed cows. Protozoa engulfs rumen bacteria cells up to 20,000 cells per hour (Dehority, 2003). This pronounced effect of protozoa on the bacterial activities in the rumen (Williams and Coleman, 2012) may explain the increased bacterial count with the inclusion of SO, SA, and SASO additives.

Sunflower oil and SA increased total bacterial counts and MCP production suggesting an increase in the availability of energy for microbial growth. Previously, it was found that feeding SA shifted ruminal bacteria toward cellulolytic population instead of amylolytic bacteria in the rumen of SA-fed dairy cow (Boeckaert et al., 2007). While the decreased protozoa can be a reason for increased bacterial number because protozoa engulf rumen bacteria cell up to 20,000 cells per hour (Dehority, 2003), therefore, bacterial cell number could be multiplied after protozoal decline.

\subsection{Fermentation parameters}

Inoculum source $\times$ additive type and inoculum source $\times$ additive type $\times$ dose interactions were observed for fermentation SCFA, ammonia-N, OMD, ME, $\mathrm{PF}_{24}, \mathrm{GY}_{24}$, and MCP (Table 5). Inoculum source altered the $\mathrm{pH}, \mathrm{SCFA}, \mathrm{OMD}, \mathrm{ME}, \mathrm{PF}_{24}$, $\mathrm{GY}_{24}$, and MCP of the incubation medium. Both inoculum sources and additives at all doses significantly decreased $(P<0.001)$ fermentation $\mathrm{pH}$ and increased ammonia- $\mathrm{N}(P<0.001)$, as well as DMD $(P<0.05)$. The goat inoculum at levels $1,2,4$ and $5 \%$ of SO, 
levels 2, 3 and 5\% of SA and the levels 1 and 3\% of SASO significantly increased $(P<0.001)$ SCFA, OMD, ME, GY 24 , and MCP but decreased $\mathrm{PF}_{24}$ (Table 5). The inoculum from steers at levels 1,4 and $5 \%$ of $\mathrm{SO}$ and $2 \%$ of SA quadratically increased $(P<0.003)$ SCFA, OMD, ME, $\mathrm{GY}_{24}$, and MCP but decreased $(P=0.001) \mathrm{PF}_{24}$. All levels of SASO quadratically decreased $(P=0.003)$ SCFA, OMD, ME, GY 24 , and MCP but increased $(P=0.001) \mathrm{PF}_{24}$.

The feed additives improved fermentation parameters in a dosedependent manner. Both of SO and SA decreased fermentation $\mathrm{pH}$. However, the reported values of fermentation $\mathrm{pH}$ were within the range of $6.38-6.49$, which is above the values that might negatively affected rumen function (de Veth and Kolver, 2001). The reported values in Table 5 indicate a normal ruminal fermentation environment for the culture medium. The lower ruminal $\mathrm{pH}$ may be related to the increased concentration of ammonia and total SCFA observed with the additive supplementation (Sucu et al., 2017), or due to increased energy density (Morsy et al., 2015) in the diets. The increased total SCFA production and decreased $\mathrm{pH}$ reflect a higher extent of fermentation with the inclusion of SO and SA. The greater SCFA and ME were a result of improved fermentation and OMD with the additives, and may be due to improved synchronization between energy and $\mathrm{N}$ release in the ruminal medium. Morsy et al. (2015) observed a decline in ruminal pH and an increase in SCFA concentration with the inclusion of SO at $20 \mathrm{~mL} / \mathrm{d}$ in the diet of goats.

Sunflower oil and SA increased ammonia-N, which may be because of increased bacterial count with the inclusion of SO and $\mathrm{SA}$, and with the presence of soybean meal as the main protein source in the total mixed ration. The enhanced microbial activity and nutrients degradation due to increased total ruminal bacterial numbers in response to the inclusion of SO and SA in the diet has been linked to an increase in SCFA production (Morsy et al., 2015; Sucu et al., 2017). Ueda et al. (2003) observed that the inclusion of flaxseed oil increased ruminal ammonia concentration in dairy cows due to increasing bacterial $\mathrm{N}$ flow with SO.

Sunflower oil and SA enhanced total mixed ration degradability because of increasing total bacterial count and MCP production. Narimani-Rad et al. (2012) observed that the inclusion of SO at 0 , 2.5 or $5 \%$ of a forage-based diet did not affect ME, OMD, and net energy of diets. Sucu et al. (2017) observed that feeding lambs on diets supplemented with SA at $5 \mathrm{~g} / \mathrm{d}$ increased ruminal SCFA concentration and decreased rumen $\mathrm{pH}$, without affecting ruminal ammonia- $\mathrm{N}$ concentration.

These improved fermentation kinetics as OMD, ME, GY 24 , and MCP in steer compared with goat inoculum do not support the often-stated superiority of goats over cattle in terms of nutrients digestibility (Domingue et al., 1991).

\section{Conclusion}

The tested feed additives could be used to improve feed utilization, and to reduce biogases production for sustainable livestock production and the improvement of environmental conditions. The optimal levels of feed additives for sunflower oil were at $1-3 \%$, Schizochytrium microalgae at $1-2 \%$, and their mixture at $1-2 \%$. The reduced diet's nutritive value with some levels, and increases with other levels, suggests it may be possible to prepare appropriate doses and mixtures of algae and sunflower oil to obtain both methane reduction, and maintain or improve feed utilization. These observations imply that the in vitro evaluation of feeds using different inoculums could be recommended to examine differences between animal species. More research is however desirable to determine whether Schizochytrium microalgae and sunflower oil or their mixture could be used as feed additives for improving the environmental conditions and affect feed utilization and methane production in dairy and beef cattle, goats and steers.

\section{Conflict of interest}

All authors declare that there are no present or potential conflicts of interest among the authors and other people or organizations that could inappropriately bias their work.

\section{Acknowledgements}

Authors would like to thank the financial support from Universidad Autónoma del Estado de México (Project UAEM 4304/ 2017/CI). Authors also acknowledge A.E. Kholif by providing the commercial sample of Schizochytrium microalgae used in this experiment.

\section{References}

Abubakr, A.R., Alimon, A.R., Yaakub, H., Abdullah, N., Ivan, M., 2013. Digestibility, rumen protozoa, and ruminal fermentation in goats receiving dietary palm oil by-products. J. Saudi Soc. Agric. Sci. 12 (2), 147-154.

Aderinboye, R.Y., Akinlolu, A.O., Adeleke, M.A., Najeem, G.O., Ojo, V.O.A., Isah, O.A., Babayemi, O.J., 2016. In vitro gas production and dry matter degradation of four browse leaves using cattle, sheep and goat inocula. Slov. J. Anim. Sci. 49 (1) 32-43.

AOAC, 1997. Association of Official Analytical Chemists. Official Methods of Analysis, sixteenth ed. AOAC, Arlington, VA, USA.

Beauchemin, K.A., Kreuzer, M., O'Mara, F., McAllister, T.A., 2008. Nutritional management for enteric methane abatement: a review. Aust. J. Exp. Agric. 48, 21-27.

Beauchemin, K.A., McGinn, S.M., Petit, H.V., 2007. Methane abatement strategies for cattle: lipid supplementation of diets. Can. J. Anim. Sci. 87 (3), 431-440.

Blümmel, M., Steingss, H., Becker, K., 1997. The relationship between in vitro gas production, in vitro microbial biomass yield and ${ }^{15} \mathrm{~N}$ incorporation and its implications for the prediction of voluntary feed intake of roughages. Br. J. Nutr. 77, 911-921.

Boeckaert, C., Vlaeminck, B., Mestdagh, J., Fievez, V., 2007. In vitro examination of DHA-edible micro algae: 1 . Effect on rumen lipolysis and biohydrogenation of linoleic and linolenic acids. Anim. Feed Sci. Technol. 136 (1), 63-79.

Broderick, G.A., Kang, J.H., 1980. Automated simultaneous determination of ammonia and total amino acids in ruminal fluid and in vitro media. J. Dairy Sci. 63, 64-75.

Burnett, V.F., Jacobs, J.L., Norng, S., Ponnampalam, E.N., 2017. Feed intake, liveweight gain and carcass traits of lambs offered pelleted annual pasture hay supplemented with flaxseed (Linum usitatissimum) flakes or algae (Schizochytrium sp.). Anim. Prod. Sci. 57 (5), 877-883.

Chilliard, Y., Ferlay, A., Rouel, J., Lamberet, G., 2003. A review of nutritional and physiological factors affecting goat milk lipid synthesis and lipolysis. J. Dairy Sci. 86 (5), 1751-1770.

Cone, J.W., Van Gelder, A.H., Bachmann, H., 2000. Influence of inoculum source, dilution and storage of rumen fluid on gas production profiles. In: Gas Production: Fermentation Kinetics for Feed Evaluation and to Assess Microbial Activity. Proceedings of the EAAP Satellite Symposium on Gas Production, Wageningen, The Netherlands. Proc. Br. Soc. Anim. Sci, pp. 15-16.

de Veth, M.J., Kolver, E.S., 2001. Diurnal variation in $\mathrm{pH}$ reduces digestion and synthesis of microbial protein when pasture is fermented in continuous culture. J. Dairy Sci. 84 (9), 2066-2072.

Dehority, B.A., 2003. Rumen Microbiology. Nottingham University Press, Nottingham, NG11 OAX, UK, p. 372.

Dohme, F., Machmüller, A., Wasserfallen, A., Kreuzer, M., 2001. Ruminal methanogenesis as influenced by individual fatty acids supplemented to complete ruminant diets. Lett. Appl. Microbiol. 32 (1), 47-51.

Domingue, B.F., Dellow, D.W., Wilson, P.R., Barry, T.N., 1991. Comparative digestion in deer, goats, and sheep. N. Z. J. Agric. Res. 34 (1), 45-53.

Elghandour, M.M.Y., Kholif, A.E., Salem, A.Z.M., de Oca, R.M., Barbabosa, A. Mariezcurrena, M., Olafadehan, O.A., 2016. Addressing sustainable ruminal methane and carbon dioxide emissions of soybean hulls by organic acid salts. J. Clean. Prod. 135, 194-200.

Elghandour, M.M.Y., Vázquez, J.C., Salem, A.Z.M., Kholif, A.E., Cipriano, M.M., Camacho, L.M., Márquez, O., 2017. In vitro gas and methane production of two mixed rations influenced by three different cultures of Saccharomyces cerevisiae. J. Appl. Anim. Res. 45 (1), 389-395.

Fedorak, P.M., Hrudey, S.E., 1983. A simple apparatus for measuring gas production by methanogenic cultures in serum bottles. Environ. Technol. 4, 425-432.

Fievez, V., Boeckaert, C., Vlaeminck, B., Mestdagh, J., Demeyer, D., 2007. In vitro examination of DHA-edible micro-algae: 2 . Effect on rumen methane production and apparent degradability of hay. Anim. Feed Sci. Technol. 136, 80-95.

FAO, 2006. Livestock's Long Shadow - Environmental Issues and Options. Food and Agriculture Organization, Rome, Italy, ISBN 92-5-105571-8.

France, J., Dijkstra, J., Dhanoa, M.S., Lopez, S., Bannink, A., 2000. Estimating the 
extent of degradation of ruminant feeds from a description of their gas production profiles observed in vitro: derivation of models and other mathematical considerations. Br. J. Nutr. 83, 143-150.

Getachew, G., Makkar, H.P.S., Becker, K., 2002. Tropical browses: contents of phenolic compounds, in vitro gas production and stoichiometric relationship between short chain fatty acid and in vitro gas production. J. Agric. Sci. Camb. $139,341-352$.

Girard, V., Hawke, J.C., 1978. The role of holotrichs in the metabolism of dietary linoleic acid in the rumen. Biochem. Biophys. Acta 528, 17-27.

Goering, M.K., Van Soest, P.J., 1970. Forage Fiber Analysis (Apparatus, Reagents, Procedures and Some Applications). Agriculture Handbook, No 379. Agricultura Research Service, USDA, Washington, DC.

Hernandez, A., Kholif, A.E., Lugo-Coyote, R., Elghandour, M.M.Y., Cipriano, M., Rodríguez, G.B., Odongo, N.E., Salem, A.Z.M., 2017. The effect of garlic oil xylanase enzyme and yeast on biomethane and carbon dioxide production from 60-d old Holstein dairy calves fed a high concentrate diet. J. Clean. Prod. 142, 2384-2392.

Hook, S.E., Wright, A.D.G., McBride, B.W., 2010. Methanogens: methane producers of the rumen and mitigation strategies. Archaea 2010, 11. http://dx.doi.org 10.1155/2010/945785. Article ID 945785.

Johnson, K.A., Johnson, D.E., 1995. Methane emissions from cattle. J. Anim. Sci. 73, 2483-2492.

Jordan, E., Lovett, D.K., Hawkins, M., Callan, J.J., O'Mara, F.P., 2006. The effect of varying levels of coconut oil on intake, digestibility and methane output from continental cross beef heifers. J. Anim. Sci. 82 (06), 859-865.

Kelly, O., Cusack, S., Jewell, C., Cashman, K.D., 2003. The effect of polyunsaturated fatty acids, including conjugated linoleic acid, on calcium absorption and bone metabolism and composition in young growing rats. Br. J. Nutr. 90 (4), 743-750.

Kholif, A., Morsy, T., Matloup, O., Anele, U., Mohamed, A., El-Sayed, A.B., 2017. Di etary Chlorella vulgaris microalgae improves feed utilization, milk production and concentrations of conjugated linoleic acids in the milk of Damascus goats. J. Agric. Sci. 155 (3), 508-518.

Kholif, A.E., Morsy, T.A., Abd El Tawab, A.M., Anele, U.Y., Galyean, M.L., 2016. Effect of supplementing diets of Anglo-Nubian goats with soybean and flaxseed oils on lactational performance. J. Agric. Food Chem. 64, 6163-6170.

Martin, C., Morgavi, D.P., Doreau, M., 2010. Methane mitigation in ruminants: from microbe to the farm scale. Animal 4, 351-365.

Meale, S.J., McAllister, T.A., Beauchemin, K.A., Harstad, O.M., Chaves, A.V., 2012 Strategies to reduce greenhouse gases from ruminant livestock. Acta Agric Scandin. Sect. A Anim. Sci. 62, 199-211.

Menke, K.H., Raab, L., Salewski, A., Steingass, H., Fritz, D., Schneider, W., 1979. The estimation of the digestibility and metabolizable energy content of ruminant feeding stuffs from the gas production when they are incubated with rumen liquor in vitro. J. Agric. Sci. Camb. 93, 217-222.

Moate, P.J., Williams, S.R.O., Hannah, M.C., Eckard, R.J., Auldist, M.J., Ribaux, B.E. Jacobs, J.L., Wales, W.J., 2013. Effects of feeding algal meal high in docosahexaenoic acid on feed intake, milk production, and methane emissions in dairy cows. J. Dairy Sci. 96, 3177-3188.

Morsy, T.A., Kholif, S.M., Kholif, A.E., Matloup, O.H., Salem, A.Z.M., Elella, A.A., 2015.
Influence of sunflower whole seeds or oil on ruminal fermentation, milk production, composition, and fatty acid profile in lactating goats. Asian Australas. J. Anim. Sci. 28, 1116-1122.

Mould, F.L., Kliem, K.E., Morgan, R., Mauricio, R.M., 2005. In vitro microbial inoculum: a review of its function and properties. Anim. Feed Sci. Technol. 123, $31-50$.

Narimani-Rad, M., Nahand, M.K., Shahryar, H.A., Maheri-Sis, N., Nobar, R.S., Lotfi, A., 2011. Influence of sunflower oil supplementation on in vitro gas production of mixed ration for ruminants. Eur. J. Exp. Biol. 1, 125-129.

Narimani-Rad, M., Shahryar, H.A., Nahand, M.K., Lotfi, A., 2012. Effect of sunflower oil supplementation on in vitro fermentation patterns of forage based diets for ruminant. Bull. Env. Pharmacol. Life Sci. 1, 73-77.

Newbold, C.J., Chamberlain, D.G., 1988. Lipids as rumen defaunating agents. Proc. Nutr. Soc. 47, 154A.

Nkrumah, J.D., Okine, E.K., Mathison, G.W., Schmid, K., Li, C., Basarab, J.A., Price, M.A., Wang, Z., Moore, S.S., 2006. Relationships of feedlot feed efficiency, performance, and feeding behavior with metabolic rate, methane production, and energy partitioning in beef cattle. J. Anim. Sci. 84, 145-153.

Salem, A.Z.M., 2005. Impact of season of harvest on in vitro gas production and dry matter degradability of Acacia saligna leaves with inoculum from three ruminant species. Anim. Feed Sci. Technol. 123-124P1, 67-79.

Salem, A.Z.M., López, S., Ranilla, M.J., González, J.S., 2013. Short to medium-term effects of consumption of quebracho tannins on total and parotid saliva production and composition in sheep and goats. J. Anim. Sci. 91 (3), 1341-1349.

SAS, 2002. Statistical Analysis System. User's Guide: Statistics. Ver 9.0. SAS Institute, Cary, NC.

Scholz, B., Liebezeit, G., 2012. Screening for biological activities and toxicological effects of 63 phytoplankton species isolated from freshwater, marine and brackish water habitats. Harmful Algae 20, 58-70.

Sucu, E., Udum, D., Günes, N., Canbolat, Ö., Filya, I., 2017. Influence of supplementing diet with microalgae (Schizochytrium limacinum) on growth and metabolism of lambs during the summer. Turk. J. Vet. Anim. Sci. 41 (2), 167-174.

Ueda, K., Ferlay, A., Chabrot, J., Loor, J.J., Chilliard, Y., Doreau, M., 2003. Effect of linseed oil supplementation on ruminal digestion in dairy cows fed diets with different forage: concentrate ratios. J. Dairy Sci. 86, 3999-4007.

Van Soest, P.J., Robertson, J.B., Lewis, B.A., 1991. Methods for dietary fibre, neutral detergent fibre, and non-starch carbohydrates in relation to animal nutrition. J. Dairy Sci. 74, 3583-3597.

Wanapat, M., Khampa, S., 2006. Effect of mineralized solid palm fat and feeding pattern on ruminal ecology and digestibility of nutrients in dairy steers fed on urea-treated rice straw. Pakt. J. Nutr. 5, 319-324.

Weimer, P.J., 2015. Redundancy, resilience, and host specificity of the ruminal microbiota: implications for engineering improved ruminal fermentations. Front. Microbiol. 6, 296. http://dx.doi.org/10.3389/fmicb.2015.00296.

Williams, A.G., Coleman, G.S., 2012. The Rumen protozoa. Springer Science \& Business Media.

Williams, A.G., 1989. Metabolic activities of rumen protozoa. In: Nolan, J.V., Leng, R.A., Demeyer, D.I. (Eds.), The Roles of protozoa and Fungi in Ruminant Digestion. Penambul Books, Armidale, Australia, pp. 97-126. 